Available online at https://jurnal.stmikroyal.ac.id/index.php/jurdimas

\title{
TEKNIK CEPAT BELAJAR DESAIN POSTER MENGGUNAKAN ADOBE PHOTOSHOP PADA SMANEGERI 5 TANJUNGBALAI
}

\author{
Andrinata $^{* 1}$, Havid Syafwan ${ }^{2}$, Fauriatun Helmiah ${ }^{3}$, Nurwati $^{4}$ \\ ${ }^{1,2,3}$ D3 Manajemen Informatika, STMIK ROYAL Kisaran \\ ${ }^{4}$ D3 Teknik Komputer, STMIK ROYAL Kisaran \\ email:*andrinata0202@gmail.com
}

\begin{abstract}
Community Service Activities are carried out in the form of a day training for students in designing posters using Adobe Photoshop software as a way to add and develop the abilities and creativity of students in SMA Negeri 5 Tanjungbalai. The target in this activity is the students of SMA Negeri 5 Tanjungbalai, amounting to approximately 18 people. This dedication activity is carried out using lecture, demonstration, and practice methods accompanied by questions and answers. The lecture method is used to explain the introductory concept of the introduction of Adobe Photoshop software as one of the media in processing images. The demonstration method is used to show a work process that is the stages of introducing tools in Adobe Photoshop software and knowing each of its functions, while the training method is to practice directly how to design posters in the application. While the question and answer method is to give participants the opportunity to consult to overcome obstacles in understanding the material that has been obtained. The final results of this activity are expected to add insight to students in designing posters as a way to present or convey information.
\end{abstract}

Keywords: Adobe Photoshop Software, Poster Design, Information Technology,

\begin{abstract}
Abstrak:Kegiatan Pengabdian Masyarakat ini dilaksanakan dalam bentuk pelatihan sehari bagi siswa-siswi dalam mendesain poster menggunakan software adobe Photoshopsebagai salah satu cara untuk menambah dan mengembangkan kemampuan dan kreatifitas siswa-siswi di SMA Negeri 5 Tanjungbalai.Sasaran dalam kegiatan ini adalah parasiswa-siswi SMA Negeri 5 Tanjungbalai yang berjumlah lebih kurang 18 orang.Kegiatan pengabdian ini dilakukan dengan metodeceramah, demonstrasi, dan latihan yang disertai tanya jawab. Metodeceramah digunakan untuk menjelaskan konsep pengantar dari pengenalan software adobe Photoshopsebagai salah satu media dalam mengolah gambar. Metode demonstrasidipakai untuk menunjukkan suatu proses kerja yaitu tahap-tahapmengenalan tool-tool yang ada pada software adobe Photoshopdan mengetahui masing-masing fungsinya, sedangkanmetode latihan untuk mempraktikkan langsung cara mendesain poster pada aplikasi tersebut. Sementara metode tanya jawab untukmemberi kesempatan para peserta dalam berkonsultasi untuk mengatasi kendaladalam memahami materi yang sudah didapat.Hasil akhir dari kegiatan ini diharapkan dapatmenambah wawasanbagi para siswa dalam mendesain poster sebagai salah satu cara dalam menyajikan atau menyampaikan informasi.
\end{abstract}

Kata kunci: Desain Poster, Software Adobe Photoshop, Teknologi Informasi, 
Jurdimas (Jurnal Pengabdian Kepada Masyarakat) Royal

Vol. 3 No. 1, Januari 2020, hlm. 39 - 46

DOI: https://doi.org/10.33330/jurdimas.v3i1.474

ISSN 2622-3813 (Online)

Available online at https://jurnal.stmikroyal.ac.id/index.php/jurdimas

\section{PENDAHULUAN}

Poster dapat dideskripsikan sebagai bentuk publikasi dua dimensional, satu muka, menyajikan informasi berupa data, jadwal, dan penawaran atau untuk mempromosikan sesuatu, tempat, produk, jasa, perusahaan atau organisasi. Tugas poster adalah menangkap audiens yang tengah bergerak dengan pesan yang disampaikan[1]. Poster harus mampu menyampaikan informasi atau pesan pada audiens yang sedang sibuk, hanya dalam waktu beberapa detik.Karena waktu baca begitu singkat dan dalam situasi sibuk, maka harus memilih salah satu informasi untuk dijadikan elemen kunci, yaitu elemen yang paling dominan dan memiliki daya pikat (eye-catching) paling kuat.

Saat ini, Sekolah SMA negeri 5 Tanjungbalai sudah mempunyai fasilitas laboratorium Komputer, dan sudah digunakan komputernya bagi Siswa/i yang ingin menggunakannya, hanya saja dalam proses pemanfaatannya belum begitu maksimal. Kemampuan guru dan siswa/i nya dalam menggunakan dan memanfaatkan teknologi komputer masih tergolong rendah. Hal ini dapat dilihat dari belum adanya kegiatan perlombaan tentang tema Poster yang bisa diikuti oleh siswa/i sekolah SMA 5 Tanjungbalai, dikarenakan tidak adanya ilmu/pelajaran tentang pembuatan poster tersebut disekolah.

Berdasarkan permasalahan yang dijelaskan di atas, maka kami sebagai tim pengabdian masyarakat ini sangat tertarik untuk melaksanakan kegiatan iniserta memberikan pelatihan tentangbagaimana cara cepat membuatan desain poster menggunakan photoshop. Target pengabdian ini adalah siswa/i beserta Guru SMA Negeri 5 Tanjungbalai.

\section{METODE}

Kegiatan pengabdian ini dilakukan dengan metodeceramah, demonstrasi, dan latihan yang disertai tanya jawab. Metodeceramah digunakan untuk menjelaskan konsep pengantar dari pengenalan software Adobe
Photoshop salah satu media dalam mempermudah pekerjaan manusia. Metode demonstrasidipakai untuk menunjukkan suatu proses kerja yaitu tahap-tahapmengenalan tooltool yang ada pada software Adobe Photoshopdan mengetahui masing-masing fungsinya, sedangkanmetode latihan untuk mempraktikkan langsung penggunaan aplikasi tersebut. Sementara metode tanya jawab untukmemberi kesempatan para peserta dalam berkonsultasi untuk mengatasi kendaladalam memahami materi yang sudah didapat.

\section{PEMBAHASAN}

\section{Definisi Poster}

Poster adalah media gambar yang memiliki sifat persuasif tinggi karena menampilkan suatupersoalan (tema) yang menimbulkan perasaan kuat terhadap khalayak. Bagian terpenting dari poster adalah menyampaikan pertanyaan terhadap persoalan di atas, bukan memberikan solusi atau jawabannya. Inilah yang membuat poster berbeda dengan ilustrasi biasa. Tujuan poster adalah mendorong adanya tanggapan (respon) dari khalayak dan akan lebih baik apabila kemudian digunakan sebagai media diskusi.

Kelebihan poster adalah ilustrator dapat mengembangkan dramatisasi gambar yang berseberangan, berbeda, dan menimbulkan konflik dengan pandangan khalayak. Meskipun foto dan gambar slide dapat juga digunakan dengan carayangsama, akantetapiposterlebihdiperkayadengankreasi. Fokusdantemadariposter perlu diperhatikan, dan memiliki relevansi dengan khalayak agar emosinya bisa ditangkap.

Apabila dikelompokan dalam kelompok media, poster termasuk kedalam kelompok media grafis.Yakni media visual yang menyajikan fakta, ide, atau gagasan melalui penyajian kata-kata, kalimat, angka-angka, dan symbol atau gambar.Grafis biasanyadigunakan untuk menarik perhatian, memperjelas sajian ide, dan mengilustrasikan fakta- 
Available online at https://jurnal.stmikroyal.ac.id/index.php/jurdimas

fakta sehingga menarik dan dapat diingat orang.

\section{Teknik Merancang Poster}

1. Tentukan tujuan dan penerapan poster.

2. Tentukan tempat dimana poster akan dipasang.

3. Menentukan bentuk poster

4. Sederhanakan informasi yang ingin disebarkan.

5. Merancang beberapa draft kasar pada skala kecil.

6. Memilih warna, sesuai dengan kesan yang diinginkan.

7. Memastikan bahwa pesan jelas dan dinamis.

8. Menentukan bentuk huruf, ukuran, dan jarak.

Ada 3 Komponen Penting ketika kita bekerja dengan Adobe Photoshop yakni:

1. MenuBar

2. Toolbox

3. SideBar (Layer, Channel, Navigator dll)

Untuk bekerja dengan photoshop hal yang perlu kita ketahui adalah Toolbox, berikut ini adalah beberapa komponen dari Toolbox

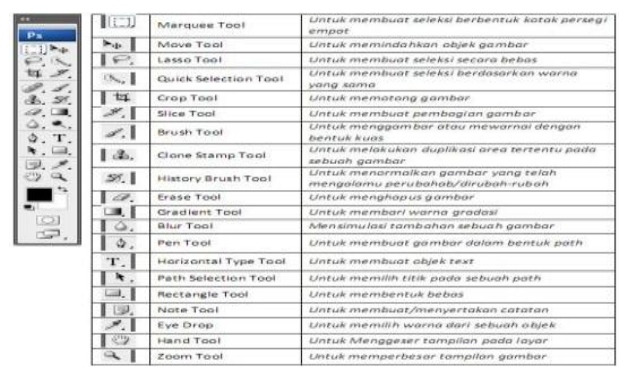

Gambar 1. Tools Adobe Photoshop

\section{Langkah - Langkah Cara Cepat Membuat Poster}

1. Buka aplikasi photoshop anda, saya disini menggunakan versi cs 6 .

2. Kemudian buka lembar kerja baru dengan cara pilih file - new perhatikan dibawah ini :

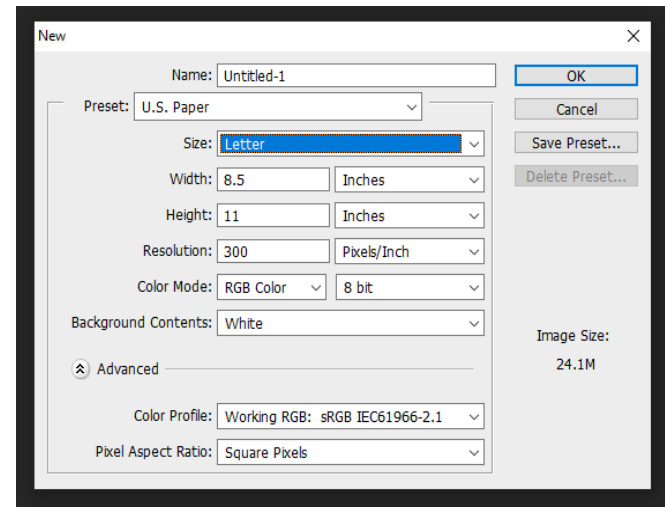

Gambar 2. Pengaturan Ukuran Kertas

3. Klik ok pada pengaturan tersebut maka akan memulai lembar kerja baru seperti dibawah ini :

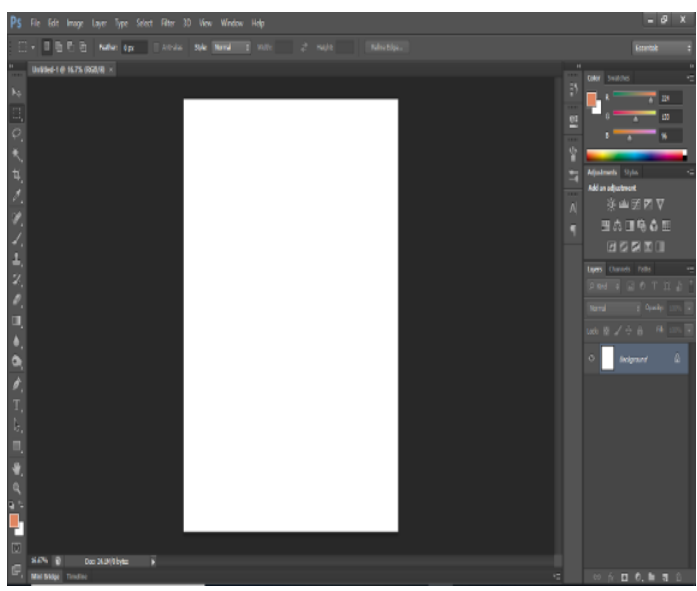

Gambar 3. Lembar Kerja Baru

4. Selanjutnya kita akan membuat background bendera. Ambil file bendera yang telah tersedia dengan cara klik file - open File Edit Image Lay
New.u
Open...

kemudian pilih file bendera yang tersedia. Jika sudah tampak file tersebut tekan OK. 
Available online at https://jurnal.stmikroyal.ac.id/index.php/jurdimas

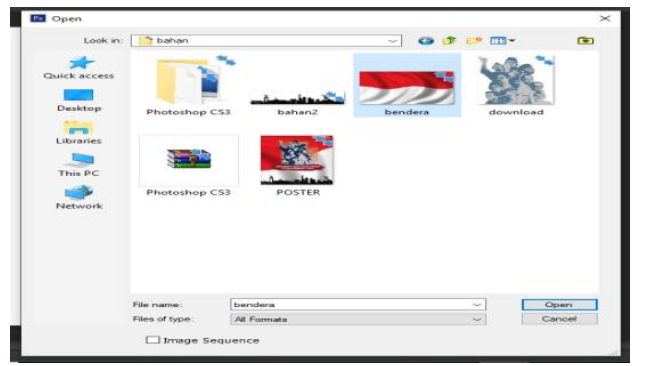

Gambar 4. Tampilan File Open untuk Pemilihan Gambar

5. Jika sudah maka akan tampil file bendera tersebut kedalam jendela photoshop

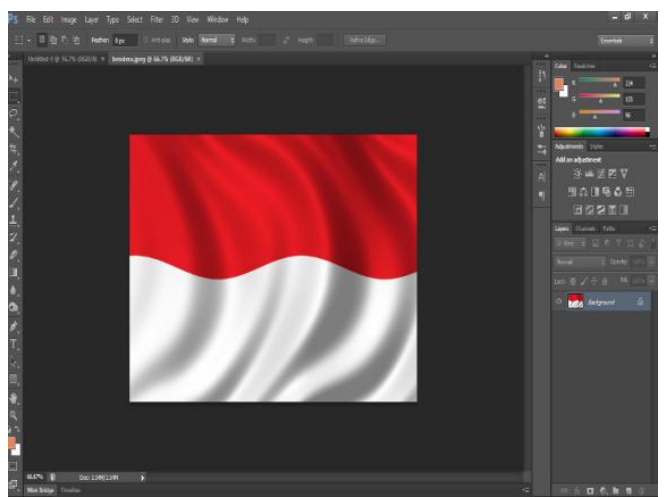

Gambar 5. Tampilan Jendela Photoshop

6. Selanjutnnya kita akan memindahkan gambar bendera tersebut kedalam lembar kerja kita dengan cara tekan kombinasi“"Ctrl + A"untuk seleksi gambar kemudian tekan $\mathrm{Ctrl}+\mathrm{C}$.

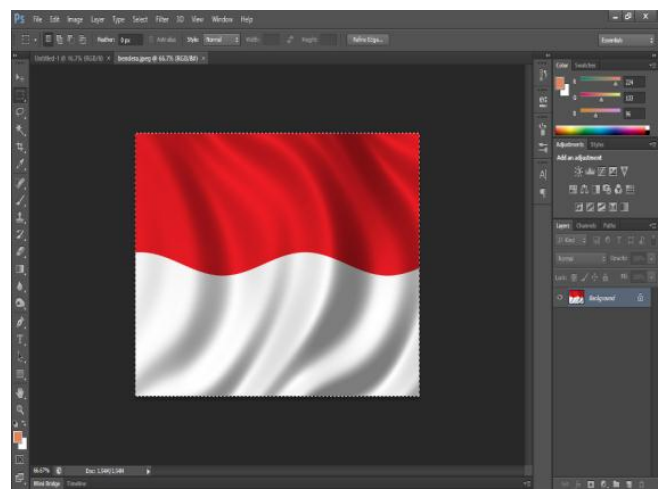

Gambar 6. Tampilan Gambar yang telah diseleksi
7. Kemudian paste kedalam lembar kerja kita dengan menekan tombol $\mathrm{Ctrl}+\mathrm{V}$

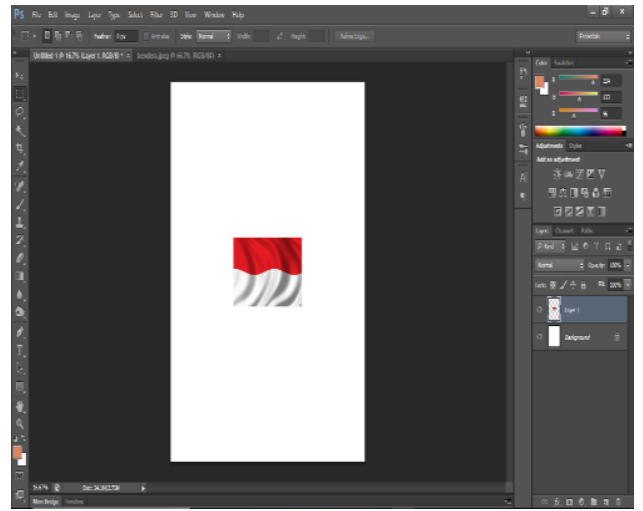

Gambar 7. Tampilan Gambar yang telah di Copy-Paste

8. Kemudian edit gambar bendera tersebut menjadi miring dengan cara menekan tombol kombinasi " $\mathrm{Ctrl}+$ T".

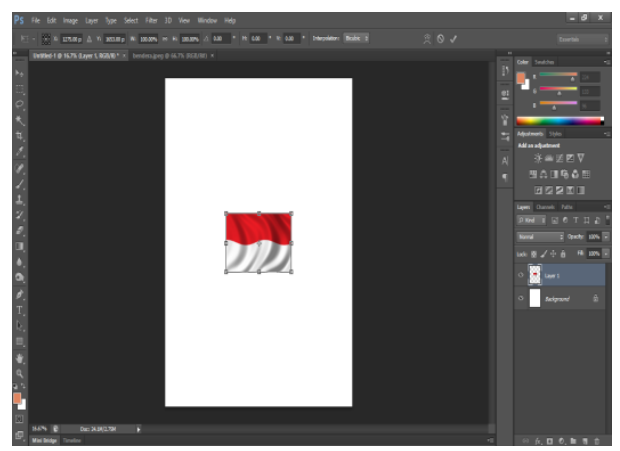

Gambar 8. Tampilan Edit Gambar

9. Setelah muncul node tarik, putar dan atur seperti gambar dibawah ini :

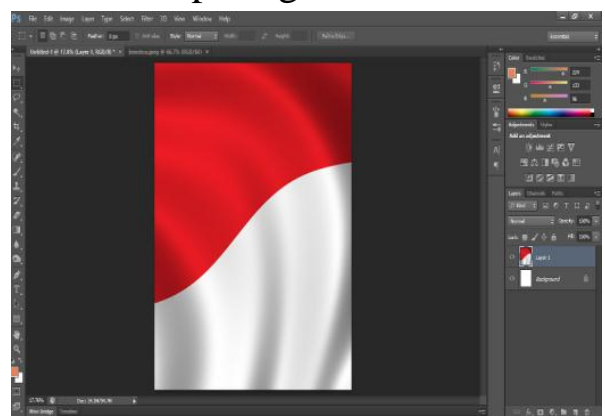

Gambar 9. Tampilan Node Tarik 
Available online at https://jurnal.stmikroyal.ac.id/index.php/jurdimas

10. Kemudian kita buat gambar asbtrak untuk background gambar pahlawan. Terlebih dahulu kita buat layer baru dengan nama "kotak1" dengan cara klik Layer- New - Layer

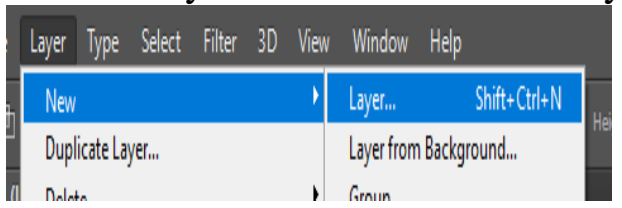

Gambar 10. Tampilan Pengaturan Layer

11. Setelah muncul gambar dibawah ini klik OK

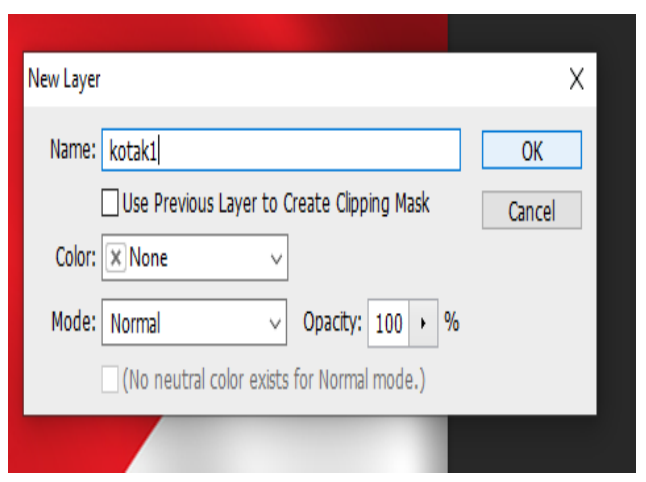

Gambar 11. Tampilan New Layer

12. Maka akan tampil layer kotak1 seperti gambar dibawah ini

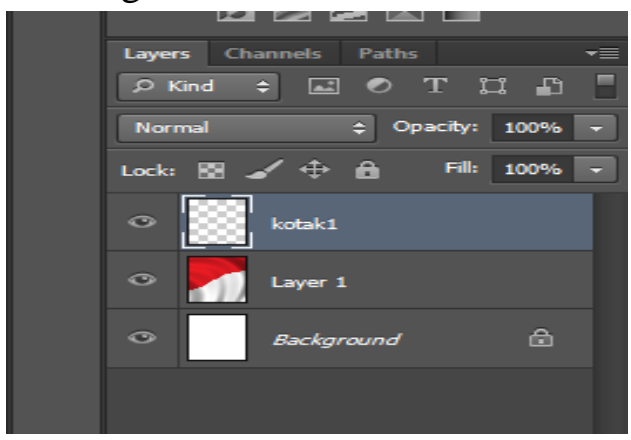

Gambar 12. Tampilan Layer Kotak 1

13. Lalu aktifkan rectangular maquee tool

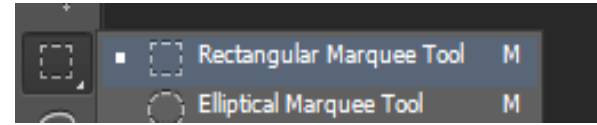

Gambar 13. Tampilan Rectangular Maquee
14. kemudian buat kotak sepert dibawah ini

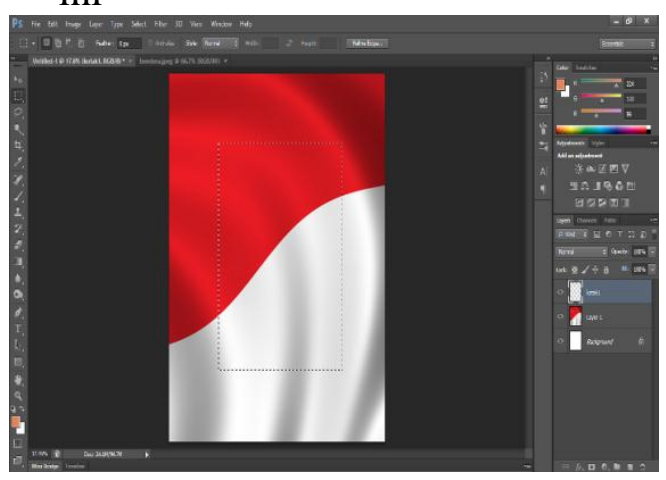

Gambar 14. Tampilan Kotak 2

15. Kemudian set warna foreground dan background $\square$ bebas mau warna apa. Setelah itu klik seperti dibawah ini

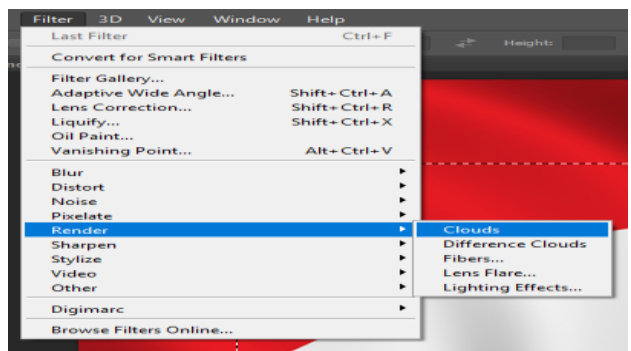

Gambar 15. Tampilan Pengaturan

16. Maka akan tampil seperti dibawah ini :

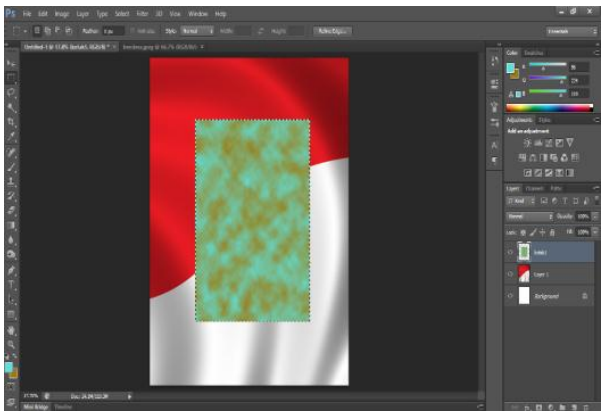

Gambar 16. Tampilan Clouds

17. Kemudian klik filter-blur-motion blur 
Available online at https://jurnal.stmikroyal.ac.id/index.php/jurdimas

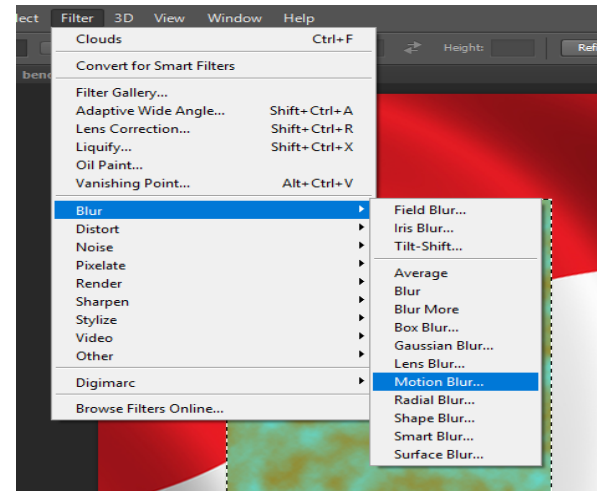

Gambar 17. Tampilan Motion Blur

18. Atur seperti tampilan dibawah ini

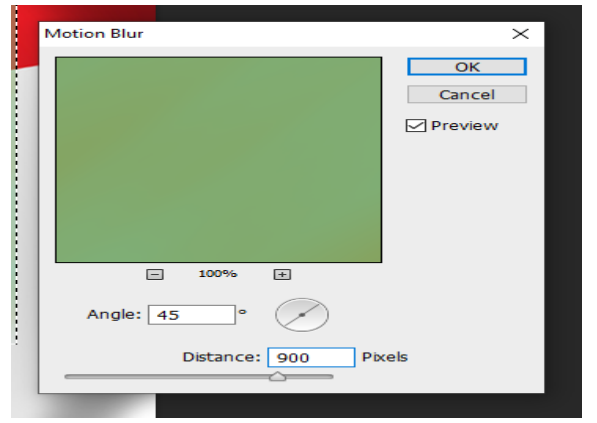

Gambar 18. Tampilan Pengaturan Motion Blur

19. Maka akan tampil seperti dibawah ini dan hilangkan tanda seleksi dengan menekan tombol kombinasi Ctrl + D

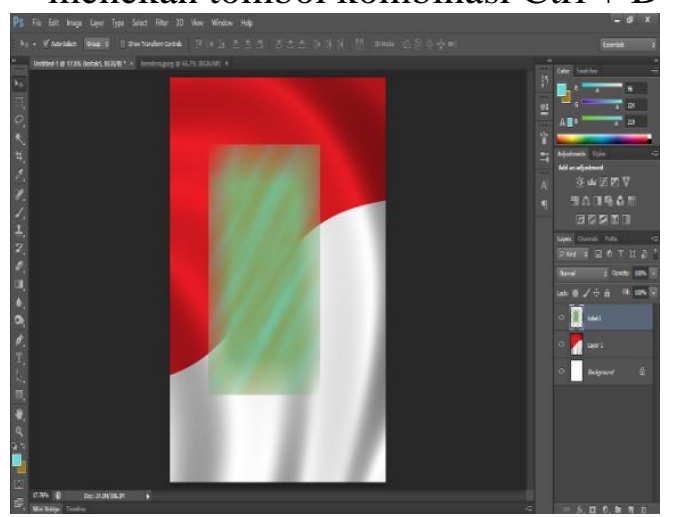

Gambar 19. Tombol Kombinasi

20. Kemudian buat satu lagi, ulangi langkah 10 dengan nama kotak2 dengan warna yang berbeda.

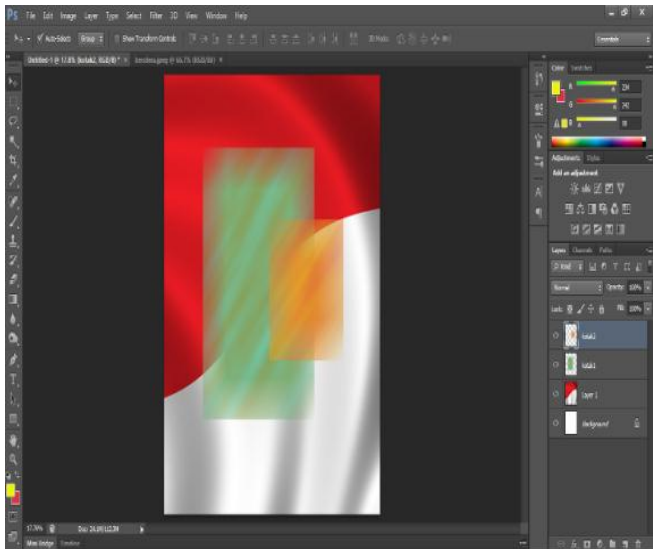

Gambar 20. Tampilan Warna Kotak 2

21. Kemudian masukkan gambar pahlawan (ulangi langkah 4 ) seperti gambar dibawah ini :

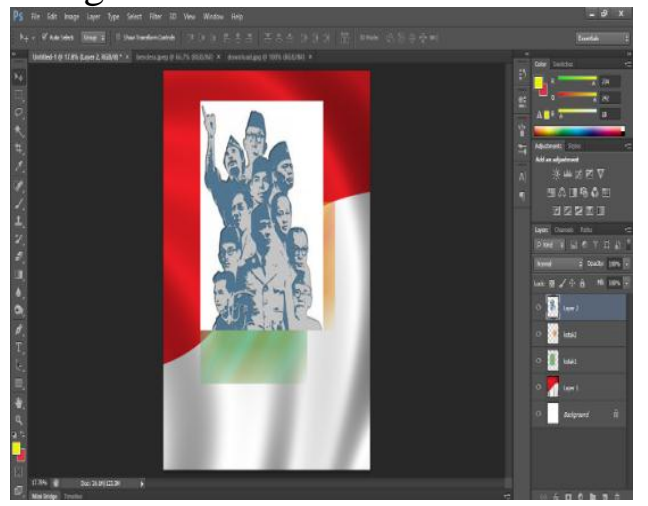

Gambar 21. Tampilan Gambar Pahlawan

22. Hilangkan background putih dengan mengaktifkan Magic Eraser Tool dengan nilai toleransi 50 .

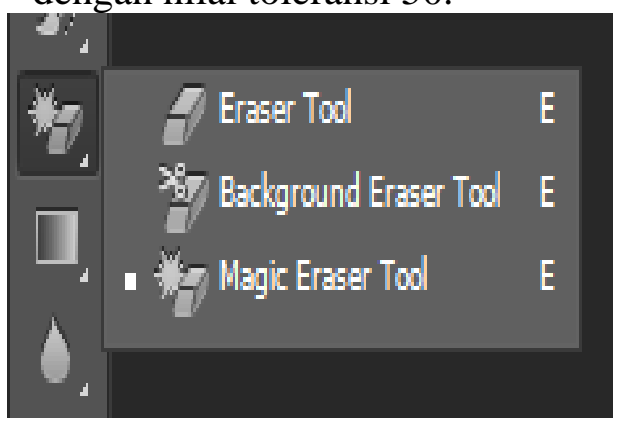

Gambar 22. Tampilan Eraser Tool

23. Maka akan tampil seperti dibawah ini : 


\section{Jurdimas (Jurnal Pengabdian Kepada Masyarakat) Royal}

Vol. 3 No. 1, Januari 2020, hlm. 39 - 46

DOI: https://doi.org/10.33330/jurdimas.v3i1.474

Available online at https://jurnal.stmikroyal.ac.id/index.php/jurdimas

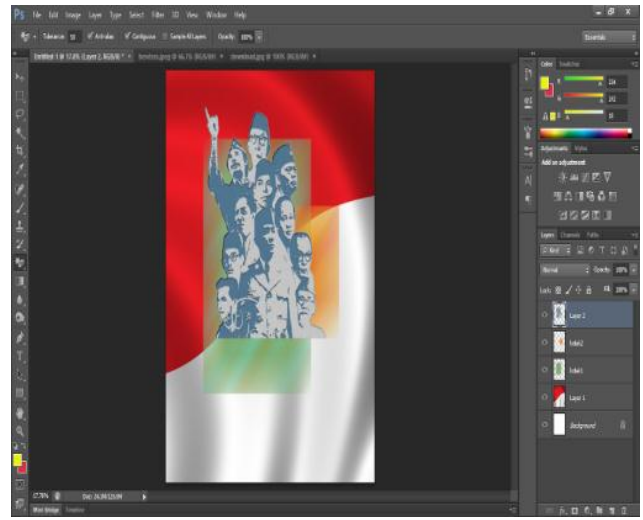

Gambar 23. Tampilan Akhir

Berikut ini dokumentasi kegiatan pengabdian kepada masyarakat dengan tema Teknik Cepat Belajar Desain Poster Menggunakan Adobe Photoshop Pada SMA Negeri 5 Tanjungbalai:

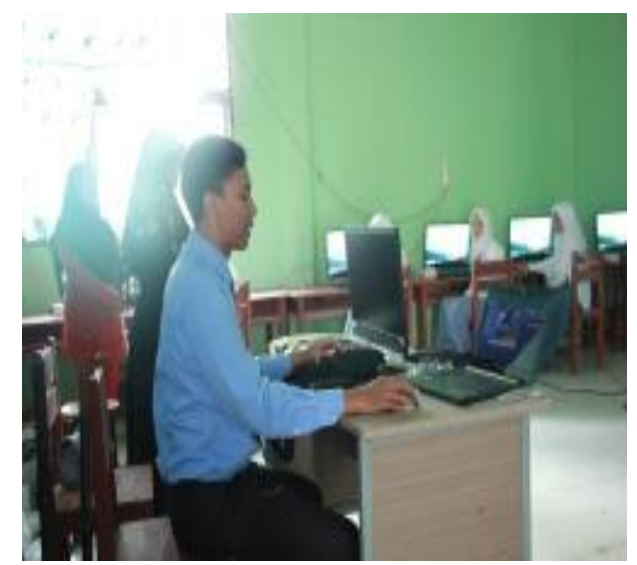

Gambar 24. Penyampaian materi oleh narasumber

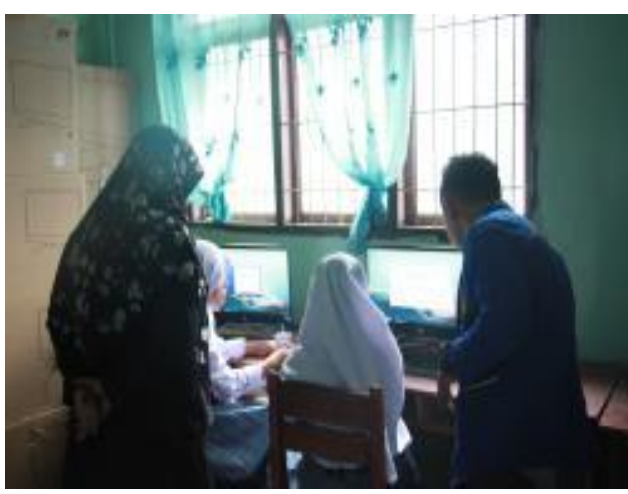

Gambar 25 Penyampaian materi oleh narasumber

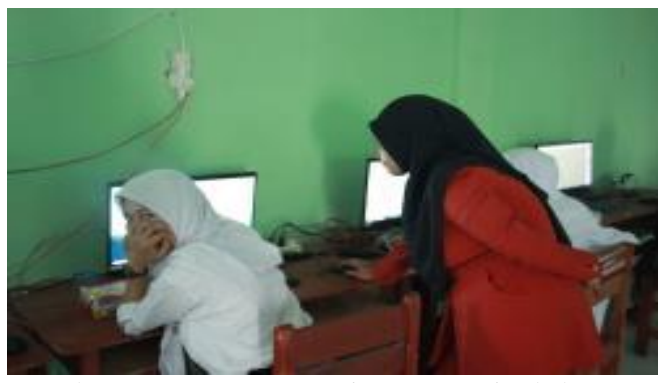

Gambar 26. Penyampaian materi oleh narasumber

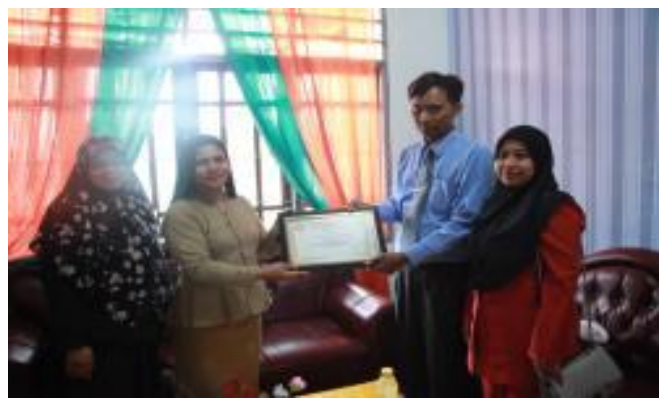

Gambar 27. Penyerahan Cinderamata kepada SMA N 5 Tanjungbalai

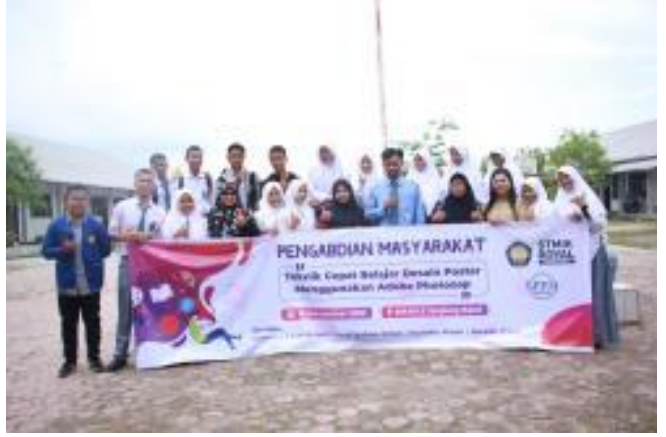

Gambar 28. Foto bersama peserta kegiatan PKM

\section{SIMPULAN}

Dari hasil evaluasi serta temuan-temuan yang diperoleh selama pelaksanaan kegiatan Pengabdian Masyarakat ini, dapat dsimpulkan bahwa program Pengabdian Masyarakat ini telah mampu memberikan manfaat yang sangat besar dan tepat sasaran bagi parasiswa SMA Negeri 5 Tanjungbalai. Bentuk pelatihan seperti ini merupakan bentuk yang sangat efektif untuk memberikan penyegaran dan tambahan wawasan serta pengetahuan di bidang teknologi informasi di luar proses 
Available online at https://jurnal.stmikroyal.ac.id/index.php/jurdimas

pembelajaran yang diterima di SMA Negeri 5 Tanjungbalai.

Untuk Pengembangan selanjutnya kami menyarankan hendaknya program-program pengabdian masyarakat seperti ini bisa dilaksanakan secara reguler dan berkala, melihat tingkat kebutuhan yang sangat tinggi akan pengenalan dan versi aplikasi-aplikasi komputer yang baru, dengan jangka waktu yang relatif singkat dalam mengikuti perkembangan teknologi secara global.

\section{UCAPAN TERIMA KASIH}

Kegiatan ini merupakan hasil dari kerjasama antara sivitas akademika STMIK Royal dengan Sekolah SMA Negeri 5 Tanjungbalai serta bantuan materi, tenaga, dan fikiran dari berbagai pihak. Untuk itu, Tim pengabdian kepada masyarakat STMIK Royal Kisaran mengucapan terima kasih yang sebesar-besarnya kepada:

1. Bapak Anda Putra Lubis, SE., MMA, Ketua Yayasan Royal Teladan Asahan, sebagai penyandang dana,
2. Ibu Dra.Hj.Roswita sebagai Kepala sekolah SMA Negeri 5 Tanjungbalai, sebagai mitra kegiatan pengabdian kepada masyarakat,

3. Tim pengabdian kepada masyarakat yang telah bekerjasama dengan baik, sehingga kegiatan dapat berjalan lancar dan sukses.

\section{DAFTAR PUSTAKA}

LPPM.(2017). Format Penulisan Jurdimas.Kisaran : STMIK Royal.

MADCOMS (2011).Kreasi Desain Poster dengan Photoshop \& CorelDRAW. Yogyakarta: Andi Publisher.

Kurniawan, Bobi. (2017). Program IPTEK bagi Inovasi dan kreativitas Kampus IT Training and Service Centre (ITSC) UNIKOM (JPKM, Vol. 3 No. 1.Hal 1825).

Hendratman, Hendi.(2016). The Magic of Adobe Photoshop.Cimahi: Informatika 